\title{
Immunological and respiratory changes in coffee workers
}

\author{
EUGENIJA ŽUŠKIN, FEDOR VALIĆ, AND BOŽICA KANCELJAK \\ From the Andrija Stampar School of Public Health and J Kajfě̌ Hospital, Zagreb, Yugoslavia
}

\begin{abstract}
Immunological status and respiratory function were studied in a group of 45 coffee workers. Skin tests with coffee allergens demonstrated the highest percentage of positive reactions to dust collected during emptying bags $(40.0 \%)$, followed by dust of green $(12 \%)$ and then roasted coffee $(8 \cdot 9 \%)$. Among 34 skin-tested control workers, $14.7 \%$ had positive skin reaction to dust collected during emptying bags, but none had positive skin reaction to green or roasted coffee. Serum levels of total $\operatorname{IgE}$ were increased in $24.4 \%$ of coffee workers and in $5.9 \%$ of control subjects. The prevalence of all chronic respiratory symptoms was significantly higher in coffee workers than in control subjects. Coffee workers with positive skin tests to coffee allergen had a significantly higher prevalence of chronic cough $(63.6 \%)$ and chronic phlegm $(72.7 \%)$ than those with negative skin tests $(32.4 \%$ and $23.5 \%$ respectively). There was a significant mean decrease over the Monday work shift in the maximum expiratory flow rate at $50 \%$ of vital capacity $\left(\mathrm{MEF}_{50}:-7 \cdot 9 \%\right)$ and at $25 \%$ vital capacity $\left(\mathrm{MEF}_{25}:-17 \cdot 8 \%\right)$, suggesting an obstructive effect mostly in smaller airways. Coffee workers with positive skin tests to coffee allergens had larger acute reductions in flow rates than those with negative skin tests but the difference was not statistically significant.
\end{abstract}

In one of our previous epidemiological studies we have shown that exposure to green or roasted coffee is likely to contribute to the development of chronic respiratory symptoms and lung function changes in exposed workers. ${ }^{1}$ Rhinitis, asthma, conjunctivitis, or dyspnoea in subjects exposed to coffee have been reported by several authors. $^{2-5}$ However, there have been few studies dealing with the more detailed immunological changes related to coffee dust exposure. ${ }^{6-10}$

In the present epidemiological investigation we have studied the relationship between some immunological tests and lung function changes.

\section{Methods}

The study was performed in 45 non-smoking female workers employed in processing roasted or green coffee. Their mean age was 31 years (range: 20 to $56 \mathrm{yr}$ ) with a mean duration of employment in the coffee industry of seven years (range: one to $18 \mathrm{yr}$ ). In addition, a group of

Address for reprint requests: Dr E Žuškin, Andrija Štampar School of Public Health, Rockefellerova 4, 41000 Zagreb, Yugoslavia.
45 non-smoking female control workers employed in the production of soft drinks was studied.

\section{IMMUNOLOGICAL STUDIES}

All coffee workers and 34 control workers were skin-tested with aqueous extracts of occupational and common allergens using the standard intradermal test. Occupational allergens were prepared from three different types of settled dust collected on operating machines in the workroom. These included roasted coffee, green coffee, and dust collected during emptying green coffee from bags. Intradermal skin tests with these allergens were performed using a dilution of $1: 500(0.02 \mathrm{ml}$ of solution). Workers were also tested with skin-test material of house dust, bacteria, Dermatophagoides pteronyssinus, moulds, histamine base $(0.1 \mathrm{mg} / \mathrm{ml})$ and buffer as control solution. Bacterial antigen consisted of $H$ influenzae, Str pneumoniae, Str viridans, Str pyogenes, Neisseria, and Staph aureus in a concentration of $60 \times 10^{6}$ in $1 \mathrm{ml}$. Mould antigen was a mixture of Alternaria, Penicillium, Mucur, Cladosporium, Aspergillus niger, and Aspergillus fumigatus in $0.2 \%$ solution. 
The skin reactions were read after 20 minutes. An intradermal skin test was considered positive if the diameter of the observed wheal was larger than $9 \mathrm{~mm}$ (corrected for the control reaction).

Serum levels of total IgE antibody were measured in coffee workers and in controls by PRIST (Pharmacia Diagnostics AB Uppsala, Sweden), a direct radioimmunological sandwich technique based on paper discs as a solid phase. ${ }^{11}$ In addition, in coffee workers concentrations of IgA, IgG, and IgM were determined by single radial diffusion on partigen plates. ${ }^{12}$

Levels of IgE below $125 \mathrm{IU} / \mathrm{ml}$ were considered normal. Values of $50-270 \mathrm{IU} / \mathrm{ml}$ for $\mathrm{IgA}, 80-220$ $\mathrm{IU} / \mathrm{ml}$ for IgG, and $60-250 \mathrm{IU} / \mathrm{ml}$ for IgM were taken as normal. Normal values of all immunoglobulins were determined according to the Behringwerke AG, Marburg-Lahn.

\section{CHRONIC RESPIRATORY SYMPTOMS}

Respiratory symptoms were recorded by using the British Medical Research Council questionnaire ${ }^{13}$ with additional questions on occupational asthma. ${ }^{14}$

Chronic cough/phlegm: cough and/or phlegm production on most days for at least three months per year.

Chronic bronchitis: cough and phlegm for a minimum of three months in the year and for not less than two successive years.

Dyspnoea grades: grade 3-shortness of breath when walking with other people at an ordinary pace on the level; grade 4-shortness of breath when walking at own pace on the level.

Occupational asthma: chest tightness, cough, wheezing, and shortness of breath during exposure to dust at work.

\section{LUNG FUNCTION MEASUREMENT}

The acute effect of exposure to coffee dust on ventilatory capacity was studied by recording the maximum expiratory flow-volume (MEFV) curves on Monday before and after work shift. The MEFV curves were recorded on a portable flowvolume spirometer ${ }^{15}$ and flow rates at $50 \%$ and at $25 \%$ of the control vital capacity $\left(\mathrm{MEF}_{50}\right.$ and $\mathrm{MEF}_{25}$ ) were read from these curves. The mean of the two highest values on successful MEFV curves was taken as the result of the test.

\section{STATISTICAL ANALYSIS}

The results of ventilatory function measurements were analysed by using the $t$ test for difference of paired (acute effects) and unpaired (chronic effects) variables. The chi-square test was used for testing differences in the prevalence of respiratory symptoms, and $\mathrm{p}<0.05$ was considered significant.

\section{Results}

IMMUNOLOGICAL STUDIES

Skin reactions to different allergens in coffee workers are presented in the figure. A positive skin reaction to the allergen of roasted coffee was found in $8.9 \%$, to that of green coffee in $12 \%$, and to the allergen prepared from the dust emmitted during emptying bags in $40 \%$ of the workers tested. Out of four workers with asthma two had positive skin reaction to coffee allergen. Among control workers, $14.7 \%$ had positive skin reaction to the allergen prepared from dust collected during emptying bags, but none to green or roasted coffee allergens.

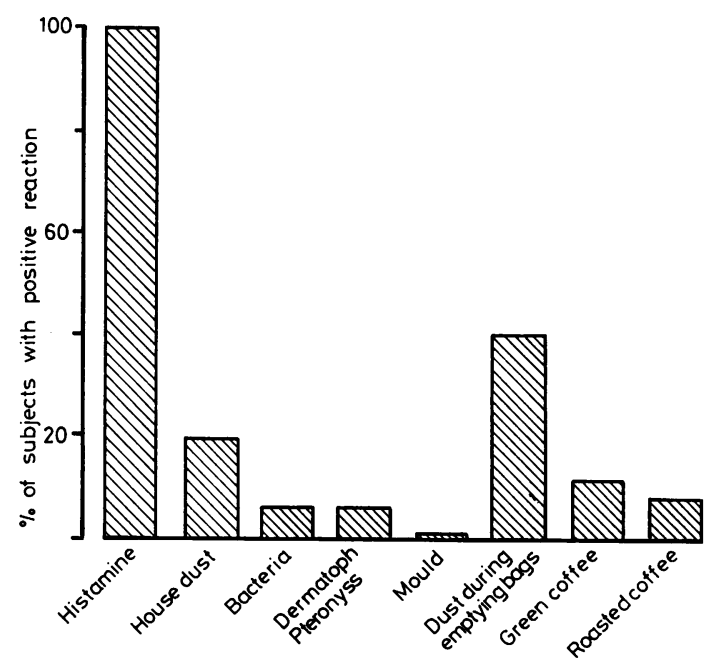

Figure Skin test reactions to occupational allergens (green coffee, roasted coffee, and dust collected during emptying bags) and to different common allergens in coffee workers.

IgE above normal level was found in $24.4 \%$ of coffee workers, and $5.9 \%$ of control subjects. While IgM in $18.2 \%$ of coffee workers was increased, its values in control subjects were normal. Out of 11 coffee workers with increased $\mathrm{IgE}$ level, seven $(64 \%)$ complained of rhinitis and conjunctivitis and also had positive skin reactions to at least one of the coffee allergens. Among four coffee workers with asthma two had increased IgE values (670 and $160 \mathrm{IU} / \mathrm{ml}$ ). Among those with increased IgM level one worker had a positive skin reaction to coffee allergens. In all those 
examined, IgA and IgG serum values were found within normal range.

\section{CHRONIC RESPIRATORY SYMPTOMS}

The prevalence of all chronic respiratory symptoms was significantly higher in coffee workers than in control subjects (table 1). A separate analysis of data obtained in workers with positive and negative skin tests respectively, indicated that the former had higher prevalence of respiratory symptoms, the difference being significant for chronic cough $(\mathrm{p}<0.05)$ and chronic phlegm $(\mathrm{p}<0.01)$. Among four subjects with asthma symptoms, two had a positive skin reaction to coffee allergen. Their durations of employment in the coffee industry were one and 17 years respectively. Thirty-eight per cent of coffee workers reported symptoms of rhinitis or conjunctivitis.

\section{VENTILATORY CAPACITY}

Table 2 shows significant acute reductions of ventilatory capacity in coffee workers over the work shift $(\mathrm{p}<0.01)$. Acute reductions in $\mathrm{MEF}_{25}$ were greater $(17 \cdot 8 \%)$ than in MEF $_{50}(7 \cdot 9 \%)$.

A comparison of pre-shift values in exposed and matched control workers (table 2) demonstrated significantly lower $\mathrm{MEF}_{50}$ and $\mathrm{MEF}_{25}$ in coffee workers than in controls $(p<0.01)$.

Workers with positive skin tests to coffee allergens (table 3) had larger acute reductions in $\operatorname{MEF}_{50}(13.3 \%)$ and in $\operatorname{MEF}_{25}(21.9 \%)$ than those with negative skin tests $\mathrm{MEF}_{50}: 6.5 \% ; \mathrm{MEF}_{25}$ : $16.2 \%$ ), but the difference between these reductions was not statistically significant $(p>0.05)$. Two workers with asthma and with positive skin tests to coffee allergen had demonstrated large acute reductions in $\mathrm{MEF}_{50}: 31 \%$ and $20 \%$ respectively, and in $\mathrm{MEF}_{25}: 18 \%$ and $33 \%$ respectively.

Pre-shift values of flow rates were found to be significantly lower in all groups of coffee workers than in the corresponding controls, except for $\mathrm{MEF}_{50}$ in those with negative skin tests.

Analysis of the acute reductions of ventilatory capacity separately in workers with normal IgE values $\left(\mathrm{MEF}_{50}:-7 \cdot 7 \% ; \mathrm{MEF}_{25}:-19 \cdot 1 \%\right)$ and in those with increased IgE values $\left(\mathrm{MEF}_{50}:-9.8 \%\right.$; $\mathrm{MEF}_{25}:-14.6 \%$ ) did not reveal significant differences in acute reductions $(p>0.05)$ between these two groups. Workers with increased IgE had sig-

Table 1 Prevalence of chronic respiratory symptoms in coffee workers

\begin{tabular}{|c|c|c|c|c|c|c|c|}
\hline Group & $\begin{array}{l}\text { Mean } \\
\text { age } \\
\text { (yr) }\end{array}$ & $\begin{array}{l}\text { Mean } \\
\text { exposure } \\
\text { (yr) }\end{array}$ & $\begin{array}{l}\text { Chronic } \\
\text { cough } \\
(\%)\end{array}$ & $\begin{array}{l}\text { Chronic } \\
\text { phlegm } \\
(\%)\end{array}$ & $\begin{array}{l}\text { Chronic } \\
\text { bronchitis } \\
(\%)\end{array}$ & $\begin{array}{l}\text { Asthma } \\
(\%)\end{array}$ & $\begin{array}{l}\text { Dyspnoea } \\
\text { grade } 3 \text { or } 4 \\
(\%)\end{array}$ \\
\hline \multirow[t]{2}{*}{$\begin{array}{l}\text { Coffee workers } \\
(n=45)\end{array}$} & 31 & 7 & 40.0 & $35 \cdot 6$ & $24 \cdot 4$ & 8.9 & 40.0 \\
\hline & & & $<0.01$ & $<0.01$ & $<0.01$ & $<0.05$ & $<0.01$ \\
\hline $\begin{array}{l}\text { Control workers } \\
(n=45)\end{array}$ & 31 & & $6 \cdot 7$ & $4 \cdot 4$ & $4 \cdot 4$ & 0 & 0 \\
\hline \multirow{2}{*}{$\begin{array}{l}\text { Workers with } \\
\text { positive skin tests } \\
(n=11)\end{array}$} & 29 & 8 & 63.6 & $72 \cdot 7$ & $45 \cdot 5$ & $18 \cdot 2$ & $45 \cdot 5$ \\
\hline & & & $<0.05$ & $<0.01$ & NS & NS & NS \\
\hline $\begin{array}{l}\text { Workers with } \\
\text { negative skin tests } \\
(n=34)\end{array}$ & 33 & 7 & $32 \cdot 4$ & $23 \cdot 5$ & $17 \cdot 6$ & $5 \cdot 9$ & $38 \cdot 2$ \\
\hline
\end{tabular}

Table 2 Ventilatory capacity in coffee workers and controls

\begin{tabular}{|c|c|c|c|c|c|c|c|c|c|c|c|c|c|}
\hline \multirow[t]{3}{*}{ Group } & \multirow{3}{*}{$\begin{array}{l}\text { Mean } \\
\text { age } \\
(y r)\end{array}$} & \multirow{3}{*}{$\begin{array}{l}\text { Mean } \\
\text { height } \\
(\mathrm{cm})\end{array}$} & \multirow{3}{*}{$\begin{array}{l}\text { Mean } \\
\text { expo- } \\
\text { sure } \\
(y r)\end{array}$} & \multicolumn{5}{|l|}{$M E F_{50}$} & \multicolumn{5}{|l|}{$M E F_{25}$} \\
\hline & & & & \multirow{2}{*}{$\begin{array}{l}\text { Before } \\
\text { shift } \\
l / s\end{array}$} & \multirow{2}{*}{$\begin{array}{l}\text { After } \\
\text { shift } \\
l / s\end{array}$} & \multicolumn{3}{|c|}{ Difference } & \multirow{2}{*}{$\begin{array}{l}\text { Before } \\
\text { shift } \\
\text { l/s }\end{array}$} & \multirow{2}{*}{$\begin{array}{l}\text { After } \\
\text { shift } \\
l / s\end{array}$} & \multicolumn{3}{|c|}{ Difference } \\
\hline & & & & & & $l / s$ & $\%$ & $p$ & & & $l / s$ & $\%$ & $p$ \\
\hline $\begin{array}{l}\text { Coffee } \\
\text { workers } \\
(n=45)\end{array}$ & 31 & 163 & 7 & $\begin{array}{r}4.80 \\
\pm 1 \cdot 29\end{array}$ & $\begin{array}{r}4.42 \\
\pm 1.38\end{array}$ & -0.38 & $-7 \cdot 9$ & $<0.01$ & $\begin{array}{r}2.25 \\
\pm 0.92\end{array}$ & $\begin{array}{l}1.85 \\
0.94\end{array}$ & -0.40 & $-17 \cdot 8$ & $<0.01$ \\
\hline $\begin{array}{l}\text { Control } \\
\text { workers } \\
(n=45)\end{array}$ & 31 & 163 & & $\begin{array}{l}5 \cdot 18 * \\
\pm 0 \cdot 70\end{array}$ & & & & & $\begin{aligned} & 2.85^{*} \\
\pm & 0.51\end{aligned}$ & & & & \\
\hline
\end{tabular}

*Difference between exposed and control workers statistically significant $(p<0.01)$. 
Table 3 Ventilatory capacity in workers with positive and negative skin tests to coffee allergens

\begin{tabular}{|c|c|c|c|c|c|c|c|c|c|c|}
\hline \multirow[t]{3}{*}{ Group } & \multicolumn{5}{|l|}{$M E F_{50}$} & \multicolumn{5}{|l|}{$M E F_{25}$} \\
\hline & \multirow{2}{*}{$\begin{array}{l}\text { Before } \\
\text { shift } \\
l / s\end{array}$} & \multirow{2}{*}{$\begin{array}{l}\text { After } \\
\text { shift } \\
l / s\end{array}$} & \multicolumn{3}{|c|}{ Difference } & \multirow{2}{*}{$\begin{array}{l}\text { Before } \\
\text { shift } \\
l / s\end{array}$} & \multirow{2}{*}{$\begin{array}{l}\text { After } \\
\text { shift } \\
l / s\end{array}$} & \multicolumn{3}{|c|}{ Difference } \\
\hline & & & $l / s$ & $\%$ & $p$ & & & $l / s$ & $\%$ & $p$ \\
\hline $\begin{array}{l}\text { Positive skin tests } \\
(n=11)\end{array}$ & $\begin{array}{c}4.35 \\
\pm 0.80 \\
5.04^{*} \\
\pm 0.68\end{array}$ & $\begin{array}{r}3 \cdot 77 \\
\pm 0.86\end{array}$ & -0.58 & $13 \cdot 3$ & $<0.01$ & $\begin{array}{c}1.87 \\
\pm 0.54 \\
2.90^{*} \\
\pm 0.34\end{array}$ & $\begin{array}{r}1.46 \\
\pm 0.45\end{array}$ & -0.41 & $21 \cdot 9$ & $<0.01$ \\
\hline $\begin{array}{l}\text { Negative skin tests } \\
(n=34)\end{array}$ & $\begin{array}{c}4.95 \\
\pm 1.39 \\
5 \cdot 20^{*} \\
\pm 0.79\end{array}$ & $\begin{array}{r}4.63 \\
\pm 1.45\end{array}$ & -0.32 & $6 \cdot 5$ & $<0.01$ & $\begin{array}{c}2.34 \\
\pm 0.99 \\
2.81^{*} \\
\pm 0.54\end{array}$ & $\begin{array}{r}1.96 \\
\pm 1.03\end{array}$ & -0.38 & $16 \cdot 2$ & $<0.01$ \\
\hline
\end{tabular}

*Control workers.

Difference between exposed and control workers statistically significant except for MEF $_{50}$ in workers with negative skin tests.

nificantly lower pre-shift values of both $\mathrm{MEF}_{50}$ $(p<0.05)$ and $\mathrm{MEF}_{25}(\mathrm{p}<0.01)$ than controls. Workers with normal IgE values had only $\mathrm{MEF}_{25}$ significantly lower than controls $(\mathrm{p}<0 \cdot 01)$.

\section{Discussion}

A significantly higher prevalence of all respiratory symptoms was found in coffee workers than in the corresponding control workers. Our results indicate a significantly higher prevalence of chronic phlegm in workers with positive than in those with negative skin tests to coffee allergens, suggesting a higher sensitivity in the former group.

The results of our previous study in two groups of female coffee workers ${ }^{1}$ have demonstrated that the mean acute reductions in FVC and $\mathrm{FEV}_{1}$ were smaller $(1 \cdot 3 \%-2 \cdot 8 \%)$ than in $\mathrm{MEF}_{50}$ and $\mathrm{MEF}_{25}$ $(4.0 \%-18.5 \%)$. This sugges's that the inhalation of dust in coffee processing caused significant bronchoconstriction with more pronounced effects in smaller airways. The acute reductions were larger in workers with positive than in those with negative skin tests. The mean pre-shift value of $\mathrm{MEF}_{25}$ in workers with positive skin tests was $64 \%$ of the corresponding value in the controls, while in those with negative skin tests it was $83 \%$. There was no significant correlation between increased IgE serum level and acute ventilatory capacity reductions.

Recently Karr et $a l^{10}$ demonstrated positive skin reactivity to green coffee bean and serum IgE antibodies specific to green coffee in six coffee workers with occupational allergic disease (asthma, rhinitis, conjunctivitis, and urticaria). Total serum IgE levels were within normal values in these workers. In our present study, out of 11 workers with increased total serum IgE antibody, eight complained of symptoms such as cough, con- junctivitis, rhinitis, and headache shortly after exposure to coffee dust.

Layton et $a l^{7}$ suggested that primary allergy to green coffee does not involve chlorogenic acid and that coffee allergy is an example of atopic hypersensitivity to proteins. Karr et $a l^{10}$ demonstrated that chlorogenic acid produced no RAST inhibition for green coffee bean.

Our previous data ${ }^{1}$ as well as the present resulis indicate that exposure to dust in coffee processing might cause the development of chronic respiratory symptoms and changes in lung function particularly in subjects with positive s'xin tes.s to coffee allergens.

The increasing frequency of positive skin reactions to allergens prepared from roasted coffee, green coffee, and the dust released during the emptying of bags, resrectively, as well as the stronger bronchocons tricting potency of green than roasted coffee found in our previous epidemiological study led us to the hypothesis that (1) some of the chemical or microbial foreign components presen $\imath$ in contents of bags of green coffee may be biologically active, (2) that the potency of these components may be decreased by heat during roasting, and (3) the potency of biologically active components of green coffee may decrease on heating. Some of our preliminary provocation tests seem to have confirmed all three assumptions but the results are not conclusive. The investigation is being continued into the comparative immunological activity heat treated and untreated dust components.

\section{References}

1 Žuškin E, Valić F, Skurić Z. Respiratory function in coffee workers. $\mathrm{Br} J$ Ind Med 1979; 36:117-22.

2 Bruun E. Allergy to coffee. An occupational disease. Acta Allergol 1957; 11:150-4. 
3 Kaye M, Freedman SO. Allergy to raw coffee: an occupational disease. Can Med Assoc J 1961; 84:469-71.

4 Turula M, Aho J, Taipale S, Förström L. Raw coffee allergy among coffee roastery workers. Proceedings of the XV International Congress of Occupational Health. Vienna: Egerman, 1966: 845-8.

5 Somazzi S, Wüthrich $\mathrm{B}$. Asthme professionnel à la poussière de café vert. Med Hyg 1975; 33:67783.

6 Pepys J, Longbottom JL, Jenkins PA. Vegetable dust pneumoconioses. Immunological responses to vegetable dusts and their flora. Am Rev Respir Dis 1964; 89:842-58.

7 Layton LL, Panzani R, Greene FC, Corse JW. Atopic hypersensitivity to a protein of the green coffee bean and absence of allergic reactions to chlorogenic acid, low-molecular-weight components of green coffee, or to roasted coffee. Int Arch Allergy 1965; 28:116-27.

8 Layton LL, Greene FC, Panzani R. Allergy to green coffee. J Allergy 1965; 36:84-91.

9 Van Toorn DW. Coffee worker's lung. A new example of extrinsic allergic alveolitis. Thorax 1970; 25:399-405.

10 Karr RM, Lehrer SB, Butcher BT, Salvaggio JE. Coffee workers' asthma: a clinical appraisal using the radioallergosorbent test. J Allergy Clin Immunol 1978; 62:143-8.

11 Wide L, Porath J. Radioimmunoassay of proteins with the use of Sephadexcoupled antibodies. Biochim Biophys Acta 1966; 130:257-60.

12 Mancini G, Carbonara AO, Heremans JF. Immunochemical quantitation of antigens by single radial immunodiffusion. Immunochemistry 1965; 2:235-54.

13 Medical Research Council Committee on the Aetiology of Chronic Bronchitis. Standardised questionnaire on respiratory symptoms. $\mathrm{Br} \mathrm{Med}$ J 1960; 2:1665.

14 Murphy RLH. Industrial diseases with asthma. In: Weiss EB, Segal MS (eds). Bronchial asthma: mechanisms and therapeutics. Little Brown, Boston, Mass: Little Brown, 1976:517-36.

15 Peters JM, Mead J, Van Ganse WF. A simple flow-volume device for measuring ventilatory function in the field. Am Rev Respir Dis 1969; 99:617-22. 